Wahana Didaktika Vol. 17 No.1 Januari 2019: 34-46

\title{
PENINGKATAN MINAT BELAJAR BAHASA INGGRIS KELAS IX.1 SMP NEGERI 11 PALEMBANG MELALUI LAYANAN BIMBINGAN DAN KONSELING KELOMPOK
}

\author{
Oleh: Hiralian \\ (Guru SMP Negeri 11 Palembang) \\ Email: hiralian@gmail.com
}

\begin{abstract}
Abstrak
Minat belajar dapat timbul dari keinginan seseorang dalam memenuhi rasa ingin tahu seseorang terhadap kegiatan tersebut Minat belajar akan membantu siswa dalam menguasai pelajarannya. Dengan demikian menjadi tanggung jawab lembaga-lembaga pendidikan untuk menyediakan lingkungan yang dapat dipercayai bagi anak-anak dan remaja guna merangsang minat belajar. Rumusan masalah yang diajukan adalah "apakah minat belajar siswa kelas IX.1 SMP Negeri 11 Palembang dapat meningkat dengan layanan bimbingan dan konseling kelompok?" Sedangkan tujuan yang akan dicapai dalam penelitian ini sebagai berikut (a) untuk meningkatkan minat belajar siswa SMP Negeri 11 Palembang kelas IX.1 melalui layanan bimbingan dan konseling kelompok. (b) untuk meningkatkan nilai ulangan harian siswa kelas IX.1 SMP Negeri 11 Palembang melalui layanan bimbingan dan konseling kelompok. Penelitian ini dilaksanakan pada kelas IX.1 berjumlah 40 siswa. Pengumpulan data menggunakan lembar observasi. Dari hasil analis didapatkan bahwa minat belajar belajar Bahasa Inggris siswa mengalami peningkatan dari siklus I sampai siklus II yaitu, siklus I $(62,92 \%)$ dan siklus II (80.85\%). Berdasarkan hasil penelitian menunjukkan bahwa terdapat pengaruh layanan bimbingan dan konseling kelompok terhadap minat belajar belajar siswa.
\end{abstract}

Kata Kunci: Bimbingan dan Konseling Kelompok, minat belajar

\section{IMPROVING CLASSIC LANGUAGE LEARNING INTEREST IN CLASS IX.1 SMP 11 STATE 11 PALEMBANG THROUGH GROUP GUIDANCE AND CONSELING SERVICES}

\begin{abstract}
Learning interest can arise from someone's desire to fulfill one's curiosity about the activity Learning interest will help students in mastering the lesson. Thus it is the responsibility of educational institutions to provide an environment that can be trusted for children and adolescents to stimulate interest in learning. The formulation of the problem proposed was "whether the interest in learning for students of class IX.1 of SMP Negeri 11 Palembang can be increased by group guidance and counseling services?" While the objectives to be achieved in this study are as follows (a) to increase the learning interest of students of SMP Negeri 11 Palembang class IX.1 through group guidance and counseling services. (b) to increase the daily test score of class IX.1 of SMP Negeri 11 Palembang through group guidance and counseling services. This research was conducted in
\end{abstract}


class IX.1 totaling 40 students. Data collection uses observation sheets. From the results of the analysis it was found that students' interest in learning English had increased from cycle I to cycle II, namely, cycle I (62.92\%) and cycle II (80.85\%). Based on the results of the study showed that there was an influence of group counseling and guidance services on the interest in student learning.

Keywords: Guidance and Group Counseling, Interest in Learning

\section{A. PENDAHULUAN}

Siswa Sekolah Menengah Pertama (SMP) rata-rata berusia 12-15 tahun. Pemberontakan siswa SMP umumnya dicirikan dengan sikap menentang dan kritis pada setiap masalah. Pemberontakan dalam pendidikan yang terlihat dari siswa SMP Negeri 11 kelas IX.1 adalah sikap kurang disiplin seperti menentang peraturan sekolah, terlibat perkelahian, malas mengerjakan tugas sekolah, terlambat sekolah, tidak mau mendengar penjelasan guru, tertidur selama pelajaran, dan membolos. Kurangnya disiplin tersebut menyebabkan penurunan minat belajar yang berdampak pada tingkat prestasi siswa.

Minat merupakan suatu sifat yang terdapat pada diri seseorang. Minat memegang peranan penting dalam proses belajar, sebab dengan minat seseorang akan melakukan sesuatu yang diminatinya. Sebaliknya, tanpa minat seseorang akan sulit bahkan cenderung tidak mungkin melakukan sesuatu. Minat berhubungan erat dengan dorongan, motif, dan reaksi emosional. Minat belajar dapat timbul dari keinginan seseorang dalam memenuhi rasa ingin tahu seseorang terhadap kegiatan tersebut Minat belajar akan membantu siswa dalam menguasai pelajarannya. Dengan demikian menjadi tanggung jawab lembaga-lembaga pendidikan untuk menyediakan lingkungan yang dapat dipercayai bagi anak-anak dan remaja guna merangsang minat belajar.

Dalam proses belajar mengajar di sekolah setiap siswa secara umum mendapat layanan pendidikan dari beberapa guru yang mengampu berbagai mata pelajaran, termasuk layanan bimbingan konseling. Hal ini dilakukan sebagai upaya membantu siswa untuk dapat melaksanakan kegiatan pembelajaran dengan layanan tanpa hambatan. Hambatan yang dimaksud adalah rendahnya minat belajar siswa sehingga menimbulkan keengganan dan ketidakmampuan dalam 
belajar, dan ketidakdisiplinan siswa selama proses belajar di sekolah. Oleh karena itu, peran guru bimbingan konseling sangat penting untuk memfasilitasi tercapainya tujuan tersebut.

Adapun layanan bimbingan dan konseling yang dipilih dan diteliti penulis untuk meningkatkan minat belajar siswa terhadap mata pelajaran Bahasa Inggris adalah kegiatan layanan bimbingan dan konseling kelompok. Bimbingan dan konseling kelompok juga dimaksudkan agar siswa SMP tidak terlalu merasa sebagai pusat perhatian. Dengan berkelompok, diharapkan siswa dapat berpartisipasi maksimal. Di samping itu anak juga belajar berpikir dan bertanggung jawab. Konseling kelompok merupakan wadah untuk menambah penerimaan diri dan orang lain, menemukan alternatif cara penyelesaian masalah dan mengambil keputusan yang tepat dari konflik yang dialaminya dan untuk meningkatkan tujuan diri dan rasa tanggung jawab pada diri sendiri dan orang lain.

Penulis melakukan Penelitian Tindakan Kelas yang berjudul: "Peningkatan Minat Belajar Bahasa Inggris Kelas IX.1 SMP Negeri 11 Palembang Melalui Layanan Bimbingan dan Konseling Kelompok Tahun Pelajaran 2016/2017" dengan harapan dapat memberikan salah satu alternatif sebagai solusi dalam upaya mengatasi kurangnya minat belajar siswa kelas IX.1 SMP Negeri 11 Palembang. Berdasarkan uraian di atas maka yang menjadi permasalahan dalam penelitian ini adalah "apakah minat belajar siswa kelas IX.1 SMP Negeri 11 Palembang dapat meningkat dengan layanan bimbingan dan konseling kelompok?"

Pertanyaan ini merupakan permasalahan yang harus dicarikan penyelesaian dalam penelitian tindakan kelas. Layanan bimbingan dan konseling kelompok ini merupakan fokus yang akan diteliti ketepatgunaannya dalam upaya meningkatkan minat belajar siswa kelas IX.1 SMP Negeri 11 Palembang terhadap mata pelajaran Bahasa Inggris. Berdasarkan rumusan masalah di atas, tujuan penelitian tindakan kelas ini adalah:

1) meningkatkan minat belajar siswa SMP Negeri 11 Palembang kelas IX.1 melalui layanan bimbingan dan konseling kelompok. 
2) meningkatkan nilai ulangan harian siswa kelas IX.1 SMP Negeri 11 Palembang melalui layanan bimbingan dan konseling kelompok

Sejalan dengan perkembangan fisik, kemampuan berpikir remaja juga berkembang pesat, mereka telah mampu berpikir tahap tinggi, berpikir logis, dan rasional. Dalam perkembangan sosial remaja mulai ingin mandiri, mereka ingin melepaskan diri dari ikatan keluarga dan membentuk ikatan dengan teman sebaya. Perubahan-perubahan yang sangat cepat dalam segi fisik dan intelektual (berpikir) rupanya menimbulkan goncangan-goncangan dalam kehidupan emosi remaja. Suasana emosi remaja, terutama remaja awal (usia SMP) mudah sekali berubah, suasana yang riang gembira mudah sekali berubah menjadi rasa sedih yang mendalam, kemanjaan kepada orang tua dengan persoalan sepele berubah menjadi rasa antipati (Supriatna, 2011).

Menurut Hikmawati (2010), di sekolah sangat mungkin ditemukan siswa yang bermasalah, dengan menunjukkan gejala penyimpangan perilaku yang merentang dari kategori ringan sampai dengan berat. Upaya untuk menangani siswa yang bermasalah, khususnya yang terkait dengan pelanggaran disiplin sekolah dapat dilakukan dua pendekatan yaitu: (1) pendekatan disiplin dan (2) pendekatan bimbingan dan konseling.

Penanganan siswa bermasalah melalui pendekatan disiplin merujuk pada aturan dan ketentuan (tata tertib) yang berlaku di sekolah beserta sanksinya memang perlu ditegakkan untuk mencegah sekaligus mengatasi terjadinya berbagai penyimpangan perilaku siswa. Kendati demikian, sekolah bukan "lembaga hukum" yang harus mengobral sanksi kepada siswa yang mengalami gangguan penyimpangan perilaku yang terjadi pada para siswanya.

Oleh karena itu, disinilah pendekatan kedua perlu digunakan, yaitu pendekatan melalui bimbingan dan konseling. Berbeda dengan pendekatan disiplin yang memungkinkan pemberian sanksi untuk menghasilkan efek jera, penanganan siswa bermasalah melalui bimbingan dan konseling justru lebih mengutamakan pada upaya penyembuhan dengan menggunakan berbagai layanan dan teknik yang ada. 
Penanganan siswa bermasalah melalui bimbingan dan konseling sama sekali tidak menggunakan bentuk sanksi apapun, tetapi lebih mengandalkan pada terjadinya kualitas hubungan interpersonal yang saling percaya di antara konselor dan siswa yang bermasalah, sehingga setahap demi setahap siswa tersebut dapat memahami dan menerima diri dan lingkungannya serta dapat mengarahkan diri guna tercapainya penyesuaian diri yang lebih baik.

Secara visual, kedua pendekatan dalam menangani siswa bermasalah dapat dilihat dalam Bagan 1 berikut.

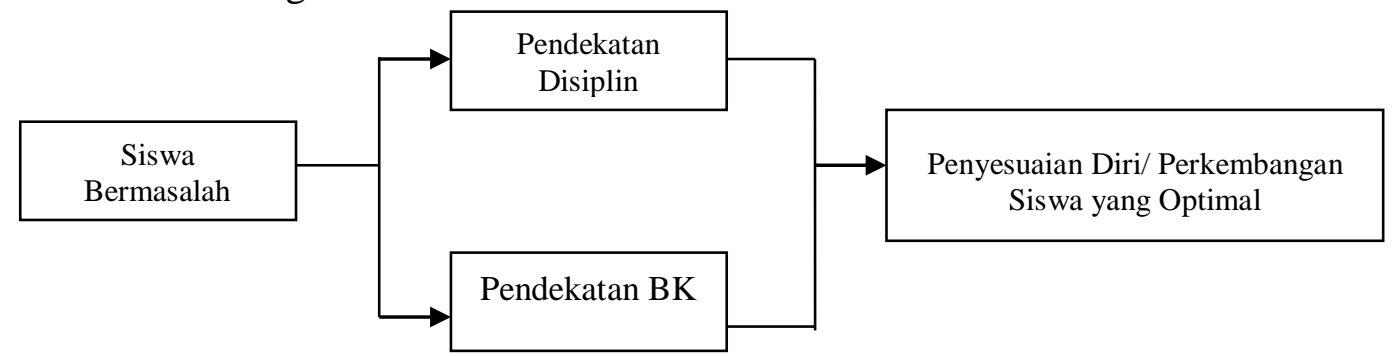

\section{Bagan 1. Pendekatan dalam Menangani Siswa Bermasalah}

Minat belajar juga dapat diartikan sebagai perasaan suka yang sangat tinggi dalam proses belajar di sekolah. Seorang siswa yang menaruh perhatian besar terhadap sesuatu (pelajaran) akan memusatkan perhatian yang lebih intensif terhadap pelajaran tersebut yang kemudian menumbuhkan semangat belajar Slameto (2003).

\section{B. METODOLOGI PENELITIAN}

Penelitian dilakukan di semester gazal selama tiga bulan, yaitu bulan September sampai dengan November tahun 2016. Penelitian ini dilaksanakan di ruang kelas IX.1 dan ruang bimbingan konseling SMP Negeri 11 Palembang, Jalan Adi Sucipto Komplek TNI AU Talang Betutu Palembang. Teknik yang digunakan dalam pengumpulan data penelitian tindakan ini adalah observasi, wawancara, dan kuesioner. Observasi digunakan untuk mengamati perilaku siswa sehari-hari dan proses belajar mengajar antara guru dengan siswa sehingga dapat memperoleh data dan mencatat data permasalahan siswa.

Wawancara dilakukan untuk memperoleh data tentang permasalahan yang dialami siswa. Wawancara dilakukan untuk memperoleh data tentang 
permasalahan yang dihadapi siswa. Prosedur pengisian kuesioner sangat mudah dan sederhana, yang terdiri dari 10 butir pernyataan. Kuesioner disusun berdasarkan gradasi Likerrt dengan tiga gradasi. Responden hanya diminta untuk memilih jawaban : Selalu, Jarang, Hampir Tidak Pernah, dan Tidak Pernah terhadap butir yang tercantum pada kuesioner tersebut sesuai dengan keadaan dirinya. Cara pemakaian dengan memberikan skors. Penskorsannya mengikuti norma-norma berikut :

1. Pada jawaban TP (Tidak Pernah) diberi skors 0 .

2. Pada jawaban HT (Hampir Tidak Pernah) diberi skors 1.

3. Pada jawaban $\mathbf{J}$ (Jarang) diberi skors 2.

4. Pada jawaban S (Sering) diberi skors 3.

Teknik pengumpulan data dilakukan melalui tiga tahap : sebelum pelaksanaan, proses pelaksanaan, dan sesudah pelaksanaan kegiatan, yaitu : mencatat hasil pengamatan, wawancara, hasil kuesioner, hasil konseling kelompok, dan hasil nilai ulangan harian; mengolah data dan merekap hasil penelitian selama proses berlangsung, dan selanjutnya diperbandingkan seberapa jauh perubahan yang terjadi pada pemahaman dan kemampuan diri siswa dalam upaya peningkatan minat belajar.

Agar data yang diperoleh valid, proses penelitian dilakukan dengan cara melakukan pengecekan dan perbandingan yaitu : a) data kuesioner siswa, wawancara, dan observasi dari beberapa sumber sebelum pelaksaan tindakan kelas dan b) data setelah adanya tindakan kelas. Dengan melakukan pengecekan, akan terlihat hasil validitas yang diperoleh.

Indikator dalam pelayanan bimbingan adalah siswa yang perlu pemahaman apa yang dimaksud dengan keputusan, hal-hal yang harus dipertimbangkan dalam mengambil keputusan, bagaimana bentuk keputusan itu dan langkah yang ditempuh dalam mengatasi keputusan, serta kapan dan dimana keputusan itu diambil. Indikator keberhasilan dalam penelitian tindakan kelas ini adalah perubahan sikap dan perilaku siswa yang positif dalam belajar setelah mendapatkan layanan konseling kelompok sehingga tujuan pokok ditargetkan 
dapat berhasil, yaitu peningkatan minat belajar siswa dapat tercapai. Indikator peningkatan minat belajar siswa adalah peningkatan nilai ulangan siswa..

\section{HASIL DAN PEMBAHASAN}

Penelitian tindakan kelas ini dilaksanakan dalam dua (2) siklus. Penelitian dilakukan di ruang kelas IX.1 dan ruang bimbingan dan konseling SMP Negeri 11 Palembang. Penelitian dilakukan dalam enam kali pertemuan dalam kurun waktu tiga bulan. Setiap bulan dilakukan dua kali pertemuan.

Pelaksanaanya diawali dengan melakukan pengamatan kegiatan belajar mengajar siswa kelas IX.1 SMP Negeri 11 Palembang. Kelas ini dipilih sebagai subjek penelitian dikarenakan keluhan beberapa guru mata pelajaran akan rendahnya minat belajar siswa yang ditandai dengan kurangnya perhatian siswa dan rendahnya nilai ulangan harian siswa, khususnya pada mata pelajaran Bahasa Inggris. Peneliti juga mengamati dan mencatat nilai ulangan harian siswa kelas IX.1 sehingga diperoleh gambaran kasar mengenai minat belajar masing-masing individu siswa. Wawancara singkat juga dilakukan untuk mengetahui penyebab rendahnya minat belajar siswa sehingga peneliti dapat merancang tindakan yang dapat meningkatkan minat belajar siswa. Berdasarkan hasil wawancara, peneliti menyusun kuesioner untuk mengklasifikasikan minat belajar siswa.

Mata pelajaran yang dipilih untuk penelitian tindakan adalah mata pelajaran Bahasa Inggris. Kedua mata pelajaran tersebut sering menjadi "momok" bagi para siswa karena sering dianggap sulit sehingga siswa menjadi malas mempelajarinya.

\section{Siklus I}

Pelaksanaan tindakan pada siklus I (satu) dilakukan dengan kegiatan yaitu

1. Mengamati proses kegiatan belajar-mengajar mata pelajaran Bahasa Inggris dan mencatat nilai ulangan harian siswa untuk memperoleh gambaran kasar mengenai profil minat belajar siswa.

2. Melakukan wawancara singkat kepada siswa untuk mencari penyebab rendahnya minat belajar siswa sehingga dapat dijadikan landasan untuk penyusunan kuesioner. 
3. Menyusun, membagikan, menjelaskan tujuan dan cara pengisian kuesioner untuk mengetahui klasifikasi tingkatan minat belajar siswa.

4. Mengevaluasi dan menganalisis kuesioner untuk mengetahui tindakan selanjutnya yang perlu dilakukan sebagai usaha meningkatkan minat belajar siswa terhadap pelajaran Bahasa Inggris.

Melalui wawancara yang dilakukan peneliti kepada 40 siswa dapat disusun kuesioner yang berisi 10 item pernyataan untuk menganalisis minat belajar masing-masing individu. Pernyataan dan jawaban siswa tersebut ditabulasikan pada Tabel 1.

Tabel 1 Tabulasi Perbandingan Jawaban Siswa dalam Upaya Peningkatan Minat Belajar Terhadap Mata Pelajaran Bahasa Inggris

\begin{tabular}{|c|l|c|c|c|c|c|}
\hline No & \multicolumn{1}{|c|}{ Pernyataan } & S & J & HT & TP & Jumlah Siswa \\
\hline 1 & Sulit untuk belajar teratur & 12 & 13 & 12 & 3 & 40 \\
\hline 2 & Sulit untuk memulai belajar & 11 & 11 & 17 & 1 & 40 \\
\hline 3 & $\begin{array}{l}\text { Sulit memusatkan perhatian } \\
\text { konsentrasi) pada waktu belajar }\end{array}$ & 6 & 11 & 21 & 2 & 40 \\
\hline 4 & $\begin{array}{l}\text { Lekas merasa lelah/pusing/bosan } \\
\text { kalau belajar }\end{array}$ & 12 & 11 & 14 & 3 & 40 \\
\hline 5 & $\begin{array}{l}\text { Merasa bahwa yang dipelajari } \\
\text { mudah sekali hilang }\end{array}$ & 13 & 11 & 12 & 4 & 40 \\
\hline 6 & $\begin{array}{l}\text { Sering timbul rasa kurang percaya } \\
\text { diri terhadap pekerjaan sendiri }\end{array}$ & 7 & 13 & 15 & 5 & 40 \\
\hline 7 & $\begin{array}{l}\text { Kurang teliti dalam mengerjakan } \\
\text { ulangan }\end{array}$ & 9 & 15 & 14 & 2 & 40 \\
\hline 8 & $\begin{array}{l}\text { Sering merasa putus asa pada } \\
\text { waktu ulangan }\end{array}$ & 7 & 15 & 12 & 6 & 40 \\
\hline 9 & $\begin{array}{l}\text { Merasa putus asa karena } \\
\text { memperoleh nilai kurang }\end{array}$ & 9 & 16 & 13 & 2 & 40 \\
\hline 10 & $\begin{array}{l}\text { Merasa tidak tahan lama berada di } \\
\text { kelas }\end{array}$ & 9 & 6 & 19 & 6 & 40 \\
\hline
\end{tabular}

Keterangan tabel :

S : Selalu, nilai skors 3

J : Jarang, nilai skors 2

HT : Hampir Tidak Pernah, nilai skors 1

TP : Tidak Pernah, nilai skors 0

Berdasarkan kuesioner yang telah diisi siswa, analisis individual dapat dilihat pada Tabel 2. Nilai skors pada setiap item pernyataan merupakan skors 
mentah. Skors mentah tersebut dikonversi menjadi skor persentil dengan menggunakan formula sebagai berikut :

$$
\text { Skor }=\text { skors mentah } / \text { skors maksimal } \times 100 \%
$$

Skor persentil tersebut dapat digunakan untuk mengidentifikasi minat belajar siswa terhadap mata pelajaran Bahasa Inggris. Pengklasifikasian minat belajar siswa sebagai berikut :
a. $0-33$
$=\quad$ minat belajar tinggi
b. $34-67$
$=\quad$ minat belajar sedang
c. $68-100$
$=\quad$ minat belajar rendah

\section{Siklus II}

Siklus II merupakan lanjutan dari siklus I, berdasarkan hasil kuesioner maka dilakukan beberapa langkah untuk menindaklanjuti hasil yang diperoleh pada siklus I, berikut tahapan persiapan pada siklus II :

1) Membentuk kelompok bimbingan dan konseling yang terdiri dari lima kelompok.

2) Mengumpulkan siswa untuk menjelaskan program bimbingan dan konseling kelompok, menawarkan siswa apakah bersedia diberikan bimbingan dan konseling, membagi kelompok, mendiskusikan program dan jadwal pertemuan

\section{PEMBAHASAN}

Tabel 2 Rata-rata Nilai Ulangan Sebelum dan Sesudah Tindakan Penelitian

\begin{tabular}{|c|c|c|}
\hline \multirow{2}{*}{ Mata Pelajaran } & \multicolumn{2}{|c|}{ Rata-Rata Nilai } \\
\cline { 2 - 3 } & I & II \\
\hline Bahasa Inggris & 65.925 & 80.85 \\
\hline
\end{tabular}

Tabel 3 Analisis Wawancara Individu yang Mendapatkan Layanan Bimbingan

\begin{tabular}{|c|c|c|c|}
\hline No & Jawaban Responden & Jumlah & Persentase \\
\hline 1 & Sangat Senang & 25 & 62,5 \\
\hline 2 & Senang & 15 & 37,5 \\
\hline 3 & Kurang Senang & 0 & 0 \\
\hline 4 & Tidak Senang & 0 & 0 \\
\hline
\end{tabular}




\begin{tabular}{|c|c|c|c|}
\hline No & Jawaban Responden & Jumlah & Persentase \\
\hline \multicolumn{2}{|c|}{ Jumlah } & 40 & 100 \\
\hline
\end{tabular}

Tabel 4 Analisis Wawancara Individu

\begin{tabular}{|c|l|c|c|}
\hline No & Jawaban Responden & Jumlah & Persentase \\
\hline 1 & Sangat Bermanfaat & 40 & 100 \\
\hline 2 & Bermanfaat & 0 & 0 \\
\hline 3 & Kurang Bermanfaat & 0 & 0 \\
\hline 4 & Tidak Bermanfaat & 0 & 0 \\
\hline \multicolumn{2}{|c|}{ Jumlah } & 40 & 100 \\
\hline
\end{tabular}

Tabel 5 Analisis Wawancara Individu yang Mengikuti Layanan Bimbingan dan Konseling Kelompok Telah Membantu Perubahan dalam Belajar Lebih Baik

\begin{tabular}{|c|l|c|c|}
\hline No & Jawaban Responden & Jumlah & Persentase \\
\hline 1 & Sangat Membantu & 31 & 77,5 \\
\hline 2 & Membantu & 9 & 22,5 \\
\hline 3 & Kurang Membantu & 0 & 0 \\
\hline 4 & Tidak Membantu & 0 & 0 \\
\hline \multicolumn{2}{|c|}{ Jumlah } & 40 & 100 \\
\hline
\end{tabular}

Setelah adanya kesepakatan, siswa diberi layanan bimbingan dan konseling kelompok yang dilaksanakan sesuai kesepakatan bersama, tempat dan waktu telah ditentukan.

\section{Pelaksanaan}

Pada tahap pelaksanaan ada tiga tahap yang dilakukan dalam kegiatan bimbingan dan konseling kelompok. Ketiga tahap kegiatan itu sebagai berikut :

Tahap 1, yaitu tahap pembentukan. Kegiatan yang dilakukan antara lain sebagai berikut :

a. Menerima kehadiran secara terbuka dan mengucapkan terima kasih.

b. Pelaksanaan diawali dengan doa.

c. Menjelaskan pengertian dan tujuan kegiatan bimbingan dan konseling kelompok.

d. Menjelaskan cara pelaksanaan dan asas kegiatan bimbingan dan konseling kelompok; aturan-aturan permainan yang harus dipatuhi dalam bimbingan 
dan konseling kelompok, yaitu menjaga asas kerahasiaan, asas kesukarelaan, dan asas keterbukaan.

e. Perkenalan dan Permainan / Pengakraban

Tahap 2, tahap peralihan. Pada tahap ini kegiatan yang dilakukan diantaranya sebagai berikut :

a. Peneliti menjelaskan kembali kegiatan yang akan ditempuh.

b. Peneliti menanyakan kesiapan setiap kelompok untuk melanjutkan kegiatan.

c. Peneliti mengenali kesiapan kelompok dalam mengatasi masalah yang muncul dari anggota kelompok.

Tahap 3, tahap kegiatan. Pada tahap ini kegiatan yang dilakukan antara lain sebagai berikut :

a. Peneliti memberikan kesempatan kepada setiap anggota kelompok untuk menyampaikan permasalahan yang dihadapi dalam memahami mata pelajaran eksakta.

b. Peneliti memfasilitasi atau menawarkan kepada anggota kelompok siapa yang pertama dengan sukarela untuk membahas atau menyampaikan masalahnya, kemudian anggota yang lain dan seterusnya.

c. Membahas masalah hingga tuntas.

d. Mengadakan sesi sharing dan tanya jawab tentang permasalahan umum yang dihadapi siswa dalam belajar mata pelajaran eksakta (Bahasa Inggris dan IPA Terpadu).

e. Membantu siswa mengenali gaya belajar mereka sehingga mereka dapat belajar lebih efektif melalui diskusi kelompok

\section{Pengamatan}

Setelah setiap anggota kelompok selesai mengungkapkan permasalahan, peneliti menawarkan kepada anggota kelompok bantuan berupa pendapat, tanggapan, masukan dengan sukarela untuk memberikan bantuan berupa pendapat, tanggapan, masukan, dan saran kepada anggota lainnya sekaligus mengamati setiap anggota kelompok dalam memberikan bantuan kepada anggota kelompok lainnya. Peneliti menanyakan kepada setiap anggota mengenai kegiatan 
ini, apakah masih ada anggota yang merasa belum terbantu masalahnya dalam belajar.

Refleksi

Refleksi ini merupakan lanjutan tahap 4, yaitu tahap pengakhiran. Pada tahap ini kegiatan yang dilakukan meliputi : a) peneliti menyampaikan bahwa konseling kelompok akan diakhiri; b) peneliti memberikan evaluasi melalui bimbingan arahan, saran, dan motivasi kepada siswa agar permasalahan segera dapat terselesaikan; c) peneliti memberi ucapan terima kasih; d) pertemuan bimbingan dan konseling terakhir diakhiri dengan menonton cuplikan video motivasi dari penggalan film "Karate Kid" dan peneliti memimpin doa penutup.

Penulis membantu siswa dengan memberi bimbingan petunjuk mengenai cara belajar yang efektif dan efesien sehingga meningkatkan minat belajar siswa dalam upaya mencapai hasil yang memuaskan. Berikut cara-cara untuk mengatasi kesukaran dalam mempelajari mata pelajaran eksakta yang disampaikan oleh penulis menurut Walgito (2010).

a. Belajar secara sistematis dengan menyediakan waktu yang cukup

b. Belajar berdasarkan atas pemahaman

c. Mengadakan latihan-latihan rutin hingga bertaraf pengetahuan siap

d. Mengadakan latihan-latihan yang bersifat problem solving menuju ke insight

e. Memahami dan membenarkan kesalahan-kesalahaan yang pernah dibuat dalam menyelesaikan soal-soal (murid-murid harus dapat membedakan soalsoal rutin dan soal-soal problem solving)

Selain memberikan cara mengatasi kesukaran dalam mempelajari mata pelajaran Bahasa Inggris secara umum kepada siswa, penulis juga membantu siswa mencari dan menganalisis penyebab kesukaran yang ditemui siswa dalam belajar. Setelah penyebab tersebut diketahui, maka penulis sebagai konselor membantu siswa dalam menyusun program belajar yang efektif dengan cara :

a. Memberi pemahaman bahwa pelajaran Bahasa Inggris adalah pelajaran yang dapat digunakan untuk melatih pola pikir dan mengoptimalkan fungsi otak.

b. Mendorong siswa untuk menyukai pelajaran Bahasa Inggris dengan memberikan pemahaman bahwa pelajaran tersebut berguna untuk kebaikan 
siswa itu sendiri dan menjelaskan kerugian yang ditimbulkan karena tidak menguasai pelajaran tersebut.

c. Menjaga kesehatan dengan pola makan dan istirahat yang baik dan teratur.

d. Memberikan motivasi kepada siswa sehingga mereka mempunyai kepercayaan diri untuk mengatasi pelajaran Bahasa Inggris.

e. Membuat jadwal belajar dan melaksanakan jadwal belajar yang telah ditetapkan

f. Mendorong siswa untuk membentuk kelompok belajar dengan anggota yang sama dengan kelompok bimbingan dan konseling

\section{SIMPULAN}

Berdasarkan hasil penelitian dan hasil belajar maka dapat disimpulkan sebagai berikut

Layanan bimbingan dan konseling kelompok dapat Meningkatkan minat belajar siswa dalam mata pelajaran Bahasa Inggris pada Siswa Kelas VIII.5 SMP Negeri 11 Palembang. Setelah melaksanaan layanan bimbingan dan konseling kelompok rata-rata nilai Bahasa Inggris siswa meningkat dari rata-rata nilai ulangan pertama $(62,92)$, rata-rata nilai ulangan Bahasa Inggris kedua $(80,85)$.

\section{DAFTAR PUSTAKA}

Hikmawati Fenti. (2010). Bimbingan Konseling. Jakarta: Rajagrafindo Persada.

Slameto. (2003). Belajar dan Faktor-Faktor Mempengaruhinya. Jakarta: Rineka Cipta.

Supriatna, Mamat. (2011). Bimbingan dan Konseling Berbasis Kompetensi. Jakarta: Rajagrafindo Persada

Walgito, Bimo. (2010). Bimbingan \& Konseling (Studi \& Karier). Yogyakarta: Andi. 